\title{
DENDROGEOMORFOLOGICKÝ VÝZKUM POVODNÍ NA VELKÉM STUDENÉM POTOCE (VYSOKÉ TATRY)
}

\author{
Radek Tichavský, Hana Přecechtělová* \\ * Ostravská univerzita, Př́rodovědecká fakulta, Katedra fyzické geografie a geoekologie, \\ Chittussiho 10, 71000 Ostrava-Slezská Ostrava, Ceská republika, \\ radek.tichavsky@osu.cz, hana.precechtelova@osu.cz
}

\begin{abstract}
Dendrogeomorphic research of floods in the Vel'ký Studený potok creek (the High Tatra Mts.)

The southern slopes of the High Tatra Mts. suffer from a lack of data about the past flood events because archival records from this region are rather scarce. In addition, gauging stations with field monitoring are missing in the most dynamic (most elevated) parts of the creek. The main aim of this study is to identify the frequency of flood events in the Vel'ký Studený potok creek obtained via dendrogeomorphic methods. Sampling strategies are usually based on a large number of trees. However, this area was affected by severe wind calamities (e.g. in 2004 and 2014) resulting in the decreased number of trees suitable for sampling. Analysis of 48 increment cores from 16 individuals of Picea abies (L.) Karst allowed the identification of 11 flood events during the period 1952-2016. The strongest dendrogeomorphic signal occurred in 1958 followed by the events in 1967, 1979,2000, 2009 and 2013. This paper showed that dendrogeomorphic research based on a limited number of trees is reliable for the creation of at least minimum chronology. Furthermore, we outlined the possibilities of future reconstructions in sufficiently forested reaches of high-gradient streams in this region.
\end{abstract}

Key words: floods, dendrogeomorphology, Vel'ký Studený potok creek, Picea abies, High Tatras Mts.

\section{ÚVOD}

Horská povodí bystřinných toků po celém světě jsou typická výskytem nebezpečných hydrogeomorfologických procesů, které se periodicky opakují v závislosti na výskytu extrémních srážkových úhrnů (Gomi et al. 2004, Wilford et al. 2004 a Borga et al. 2014) či tání sněhu (Zielonka et al. 2008). Mezi tyto procesy řadíme nejčastěji povodně (bleskové povodně - angl. flash floods), hyperkoncentrované proudy (angl. hyperconcentrated flows nebo debris floods) a blokovobahenní proudy (angl. debris flows); (Stoffel a Wilford 2012). Charakteristickou vlastností spojenou s jejich výskytem je riziko, které představují v oblastech $\mathrm{s}$ vybudovanou infrastrukturou a rozvinutým cestovním ruchem (Jakob a Hungr 2005).

Vědecké studie zabývající se příčinami, výskytem a důsledky povodní jsou často zaměřené na oblasti, kde existují dostupné časové řady hydrometeorologických měření (průtoková a srážková data) sloužící $\mathrm{k}$ identifikaci a kvantifikaci jednotlivých povodňových událostí (Grešková 2001). Jedná se především o větší vodní toky $\mathrm{v}$ podhorských nebo nížinných oblastech, kde povodñová vlna svým rozlivem do nivy způsobuje značné škody na lidských obydlích (Apel et al. 2004 a Tsakiris 2014). V posledních letech je velmi aktuální fenomén bleskových povodní na malých, často antropogenně upravených vodních tocích, jejichž prríčinou jsou primárně lokalizované konvektivní srážky (Solín 2008, Gaume et al. 2009 a Pekárová et al. 2012). Relativně málo dostupných informací o frekvenci povodňových událostí je z bystřinných vodních tokù. Extrémní prírodní podmínky často znemožňují 
dlouhodobá hydrometeorologická měření v exponovaných horských povodích, a proto jsou data z takových lokalit spíše ojedinělá (Holko et al. 2011 a BallesterosCánovas et al. 2015b). Nicméně, je potřeba dodat, že právě události v povodích I. řádu (dle Strahlera 1957) jsou často iniciačním impulsem povodní v níže položených oblastech.

Morfologie horských oblastí výrazně podmiňuje vznik extrémních srážkových událostí vlivem výškového gradientu a orientace svahů vůči převládajícímu proudění větru. Tato variabilita má za následek hưře předvídatelnou lokalizaci extrémních srážek (především v letních měsících při bouřkách) a zatímco v jednom povodí dojde $\mathrm{k}$ výrazné odtokové odezvě, druhé - sousední - může zůstat zcela bez odezvy. Horská povodí často trpí nedostatkem srážkoměrných a hydrologických stanic, a proto je hydrologická bilance jednotlivých povodí těžko uchopitelná (Marchi et al. 2010 a Borga et al. 2014).

V souvislosti s globální klimatickou změnou je povodňové riziko $\mathrm{v}$ horských oblastech velmi aktuálním tématem. Předpokládaný nárůst teplot by mohl urychlit hydrologický cyklus včetně nárůstu intenzity srážek, což ve svém důsledku může vyvolat zvýšený výskyt lokálních povodní (Danihlík a Trizna 2005). Je rovněž prokázáno, že sezonalita průtoků $\mathrm{v}$ horských oblastech je velmi citlivá na teplotní změny (Barnett et al. 2005 a Ruiz-Villanueva et al. 2016). Pro kvantifikaci a možnou predikci povodňových událostí v horských oblastech do budoucna je třeba znát jejich minulou a současnou frekvenci. V současnosti nejspolehlivějš́ metodou identifikace hydrogeomorfologických procesů v zalesněných povodích bez monitoringu srážek a průtoků je datování událostí pomocí dendrogeomorfologických metod (Alestalo 1971 a Stoffel a Bollschweiler 2008). Stromy rostoucí podél břehů vodních toků jsou při větších průtocích vystaveny působení proudící vody a materiálu. Mezi nejčastější externí disturbance způsobené povodněmi patří: 1) jizvy na kmenech stromů po nárazu klastů nebo říčního dřeva, 2) naklonění stromu vlivem tlaku proudící vody a materiálu a 3) obnažení kořenového systému vlivem erozních účinků vody. Takto zasažené stromy reagují na událost tvorbou specifických růstových disturbancí ve svých letokruhových sériích. Pomocí datování těchto disturbancí jsme schopni s roční (a někdy až sezónní) přesností stanovit výskyt povodňových událostí v daném místě (Bollschweiler a Stoffel 2009 a Ballesteros-Cánovas et al. 2015b).

Jedním z míst, kde chronologie povodňových událostí zcela chybí, jsou horská povodí na jižních svazích Vysokých Tater (slovenská část). Ačkoliv existují záznamy o významných povodních v daném regionu (např. Pacl 1959), jejich bližší specifikace a lokalizace je značně omezená na podhorské oblasti, kde povodně napáchaly škody (Hlavatá et al. 2008), nebo na severní návětři Tater z polské části, kde je daná problematika již podrobně zpracována i za pomocí dendrogeomorfologického datování (Ballesteros-Cánovas et al. 2015a a Ruiz-Villanueva et al. 2016). Převážná část publikací z Tater se věnuje spíše fenoménu současného geomorfologického hazardu jako celku (Kotarba 1992, Stankoviansky a Midriak 1998 a Rączkowska 2006), ale absolutní datování hydrogeomorfologických procesů na slovenské straně je spíše sporadické. Dendrogeomorfologický výzkum zde byl aplikován pouze na datování recentních blokovobahenních proudů a sněhových lavin v Malé a Vel'ké Studené dolině (Šilhán a Tichavský 2016 a 2017). Hlavním cílem tohoto prríspěvku je přinést nové informace o výskytu povodňových událostí na Vel'kém Studeném potoce (Vel'ká Studená dolina), kde jakákoliv historická data chybí. V posledních letech (2004 a 2014) však v dané oblasti došlo k rozsáhlým 
větrným kalamitám (Koreň 2005 a Hloska et al. 2016), které zpustošily značnou část lesního porostu včetně stromů rostoucích podél vodního toku. Dalším cílem práce tedy bylo ukázat, kolik informací o výskytu povodní jsme schopni získat z omezeného množství odebraných vzorků.

\section{STUDOVANÁ OBLAST}

Vel'ká Studená dolina je typickým trogovým údolím JV svahů slovenské části Vysokých Tater (obr. 1). Údolí je rozčleněno kary a karovými stupni (tzv. hangy), které vznikaly v glaciálním prostředí svrchního pleistocénu (především v období würmu) erozním působením horských ledovců. V současnosti se zde největší měrou uplatňují periglaciální a svahové procesy; typické jsou fragmenty skalních řícení, akumulační osypy a rozsáhlá kamenná mor̆e (Rączkowska 2006, Lehotský a Lacika 2007 a Engel et al. 2015).
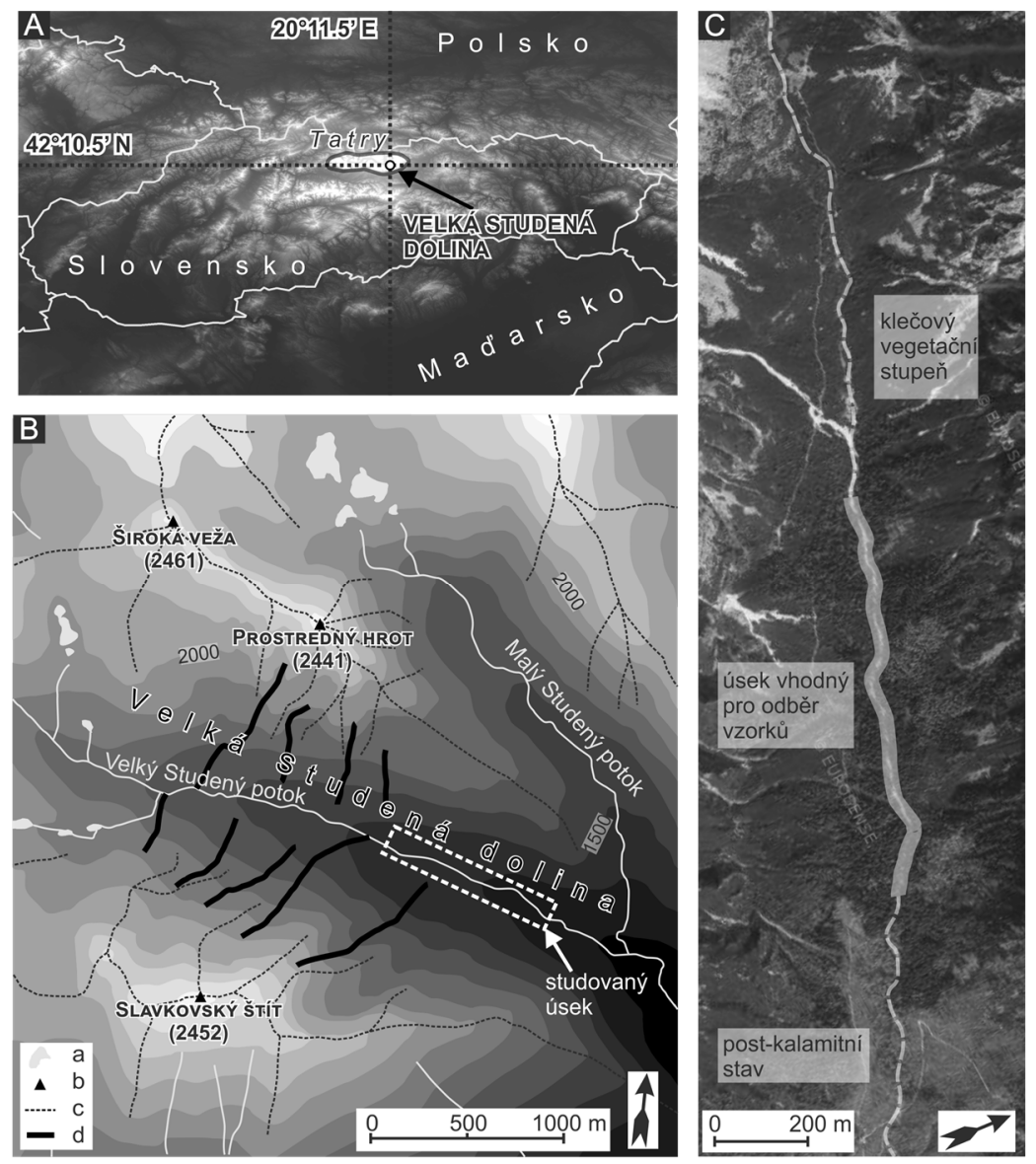

Obr. 1. Poloha studované lokality v rámci Slovenska (A) a v rámci Vel'ké Studené doliny (B): $\mathrm{a}$ - pleso, b - vrchol, c - hřbetnice , d - dráha blokovobahenního proudu. Letecký snímek

(C) znázorňuje detail zkoumaného úseku pro dendrogeomorfologický výzkum.

Podkladová data: SRTM 90m (The CGIAR Consortium for Spatial Information 2017, EUROSENSE 2015). 
Nejaktivnější oblastí z hlediska fluviálně-svahových procesů je zóna v nadmořské výšce mezi 1400 - $1650 \mathrm{~m} \mathrm{n}$. m. (obr. $1 \mathrm{~B}$ a C). Svahy nad horní hranicí lesa jsou porušeny četnými osypovými kužely a drahami blokovobahenních proudů, jejichž materiál je generován ze zavěšených (visutých) bočních údolí a strží. Některé dráhy zasahují až k údolnímu dnu a dotují tak hlavní vodní tok o sedimenty. Šilhán a Tichavský (2016) zmiňují, že během posledních deseti let došlo ke zvýšené frekvenci událostí vzniku blokovobahenních proudů, jež měly za následek i prodloužení a rozšíření transportních drah. Aktivita sněhových lavin v daném sektoru byla rovněž potvrzena jak z archivních zdrojů, tak i pomocí dendrogeomorfologického datování klečových porostů (Vojtek 2004 a Šilhán a Tichavský 2017). V oblasti pod horní hranicí lesa se tok více zařezává do údolí a vytváří korytovou morfologii kaskádového typu. Patrné jsou četné boční terasy a valy porostlé vegetací včetně náplavových kuželů, které poukazují na minulou aktivitu povodní a blokovobahenních proudů.

Vegetace pod horní hranicí lesa je tvořena převážně porosty smrku ztepilého (Picea abies (L.) Karst.) s príměsí jeřábu ptačího (Sorbus aucuparia L.) a borovice limby (Pinus cembra L.). V nadmořské výšce mezi 1450 a 1750 m n. m. již dominují porosty borovice kleče (Pinus mugo var. Mugo), které volně přecházejí do alpinského vegetačního stupně (Plesník 1971 a Kaczka et al. 2015).

Výrazným faktorem definujícím prostorové rozložení a úhrn srážek je bariérový efekt pohoří. Průměrné roční úhrny kolísají mezi 600 mm (Poprad - $690 \mathrm{~m} \mathrm{n}$. m.) a $1650 \mathrm{~mm}$ (Lomnický štít - $2632 \mathrm{~m} \mathrm{n}$. m.) a jsou obecně menší na JV svazích než na SZ svazích (1 $300 \mathrm{~mm}$, respektive $1660 \mathrm{~mm}$ v nadmořské výšce 1500 $\mathrm{m}$ n. m.). JV svahy mají vyrovnanější roční chod srážek díky zvýšenému podílu zimních srážek a sníženému podílu letních srážek. Maximální srážkové úhrny se vyskytují v letním období při krátkodobých konvektivních srážkách nebo dlouhodobých advekčních srážkách (Konček 1974). Severní návětrné svahy Vysokých Tater se vyznačují vyššími srážkovými úhrny při vlivu severních, severovýchodních a severozápadních cyklonálních synoptických situacích a díky orografickému zesílení mohou dosahovat až $300 \mathrm{~mm}$ za den, jako např. v roce 1973 (Niedzwiedz 1992 a Niedzwiedz et al. 2015). Další významné povodňové události na severní straně hor jsou známy z let 1934, 1970 a 1997. Pomocí dendrogeomorfologického datování zde byly odhaleny další období četnější povodňové aktivity mezi roky 1946 - 1949, 1955 - 1963 a 1979 - 1987 (Ballesteros-Cánovas et al. 2015a). Data o povodních z jižní strany Vysokých Tater jsou mnohem vzácnější. Nejvýraznější událostí zaznamenanou během posledních 100 let je povodeň z června 1958, která napáchala škody i v předpolí Tater. Maximální denní srážkové úhrny dosahovaly $134 \mathrm{~mm}$ ve Starém Smokovci (maximální intenzita 20,4 mm/h) a $170 \mathrm{~mm}$ na Skalnatém Plese. Na mnoha tocích byly překročeny stoleté průtoky (Pacl 1959, Konček 1974 a Holko et al. 2011). Povodně z tání sněhu nejsou v dané oblasti príliš časté vzhledem $\mathrm{k}$ odlišné době tání v různých nadmořských výškách, a tudíž rovnoměrnějšímu odtoku vody z povodí (Ruiz-Villanueva et al. 2016). Recentní události blokovobahenních proudů ve Vel'ké Studené dolině byly datovány do roků 2009 a 2013 (Šilhán a Tichavský 2016).

\section{METODIKA}

$\mathrm{V}$ rámci terénních prací jsme se zaměřili na úseku Vel'kého Studeného potoka v nadmořské výšce mezi $1350-1450 \mathrm{~m} \mathrm{n}$. m. (obr. 1 C). Pouze tento cca $1 \mathrm{~km}$ 
dlouhý úsek je porostlý smrkovým lesem a díky tomu je vhodný pro dendrogeomorfologickou rekonstrukci. Pro odběr vzorků byly vybírány pouze stromy, které vykazovaly zajizvení po př́mém impaktu materiálu transportovaného při povodni (obr. 2), přičemž orientace jizev odpovídala směru proudění (Ballesteros-Cánovas et al. 2011 a 2015a). Pomocí Presslerova přírůstového nebozezu byly z každého stromu odebrány vždy dva jádrové vývrty (proti sobě) pro získání co nejvíce informací (Bollschweiler et al. 2007). Zároveň byly odebírány vývrty z okrajů viditelných jizev pro přesné zachycení pozice jizvy v rámci letokruhových sérií (Stoffel a Corona 2014). Kromě disturbovaných stromů byly vzorkovány rovněž stromy geomorfologicky neovlivněné za účelem vytvoření referenční chronologie (Schweingruber 1996). Z celkem 20 stromů rostoucích poblíž studované lokality byla odebrána vrtná jádra $\mathrm{v}$ referenční výšce $1,3 \mathrm{~m}$. Všechny vzorky byly po transportu do laboratoře následně stabilizovány $\mathrm{v}$ dřevěných lištách a jejich povrch byl vybroušen brusnými papíry s různou zrnitostí (od nejhrubšího po nejjemnější) z důvodu lepší čitelnosti letokruhů. Pomocí měřičského stolu TimeTable a softwarů PAST4 (VIAS 2005) a ARSTAN (Cook 1985) byla sestavena referenční chronologie nutná pro identifikaci falešných či chybějících letokruhů.
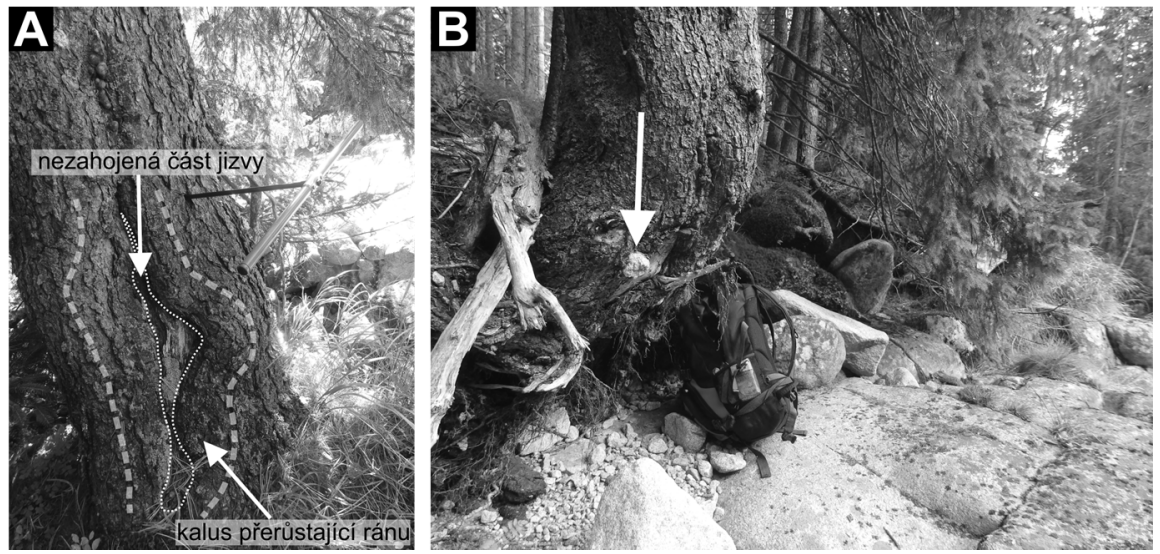

Obr. 2. Př́íklady vzorkovaných stromů

A - strategie vzorkování po okrajích přerůstající jizvy, B - ukázka nezahojené jizvy smrku na nárazovém břehu (šipka ukazuje na zarůstající klast jako pozůstatek po nárazu materiálu při povodňové vlně).

U vzorků z disturbovaných stromů byly stejným zpo̊sobem spočítány letokruhy a změřena jejich širrka. Vrámci identifikace růstových disturbancí byl kladen důraz pouze na výskyt jizev a hojivého kalusového pletiva a přítomnost tangenciálních řad traumatických pryskyřičných kanálků (TRD - angl. traumatic resin ducts; Stoffel 2008). U TRD byla navíc rozlišována intenzita signálu dle metodiky Stoffela a Corony (2014) na silné, středně silné a slabé TRD. Dle Stoffela a Corony (2014) jsou jizvy společně se silnými a středně silnými TRD jasnými indikátory hydrogeomorfologických událostí. Vzhledem k omezenému počtu vzorkovaných disturbovaných stromů (16) nebyl aplikován žádný dendrogeomorfologický index (Shroder 1978). Identifikace událostí byla výhradně založena na expertním (semikvantitativním) př́ístupu, který využívá minimálního počtu stromů disturbovaných $\mathrm{v}$ konkrétním roce a jejich logické pozici $\mathrm{v}$ rámci údolního dna 
(Bollschweiler et al. 2007, Schneuwly-Bollschweiler et al. 2013 a Tichavský et al. 2017). Pro naše účely jsme stanovili hranici minimálního počtu na dva stromy vykazující jasný růstový signál (tj. jizva, silné TRD a středně silné TRD). Ačkoliv se jedná o poměrně nízkou hranici, lze ji akceptovat při malém počtu odebíraných vzorků (Stoffel a Bollschweiler 2009, Tichavský a Șilhán 2015 a Šilhán a Tichavský 2017). Navíc pro identifikaci událostí jsme nevyužili dalších růstových disturbancí, jako např. náhlé zúžení/rozšíření letokruhů, které představují spíše doplňkové disturbance, a tudíž při omezeném počtu vzorkovaných stromủ by jejich implementace mohla vnést šum do sestavené chronologie událostí (Stoffel a Corona 2014).

\section{VÝSLEDKY}

Studovaný úsek Vel'kého Studeného potoka v nadmořské výšce mezi 1350 $1450 \mathrm{~m} \mathrm{n}$. m. vykazuje transportně-akumulační charakter, kde se střídají kaskádové úseky s morfologií stupeň-tůn̆ (step-pool). V místech s nižším gradientem se údolní dno rozšiřuje a tok se větví do více ramen, která prořezávají akumulační valy a terasy. $Z$ hlediska současné dotace sedimentů a jejich následného fluviálního transportu je zcela zásadní prrítomnost aktivních drah blokovobahenních proudi̊ nad horní hranicí lesa. Jako prríklad uved'me valy neopracovaných, nezvětralých klastů různých velikostí (od několika cm až po $2 \mathrm{~m}$ ), které pochází z nejvýraznější dráhy ústící do Vel'kého Studeného potoka v nadmořské výšce $1475 \mathrm{~m} \mathrm{n}$. m. Dosah těchto akumulací v korytě toku od vyústění dráhy je cca $100 \mathrm{~m}$. Recentní akumulace se nicméně tvoří pouze v korytě toku a nedochází tak k vybřežení materiálu na prílehlé terasy. Proto pouze stromy rostoucí na nárazových březích podél aktivního koryta vykazují známky viditelných růstových disturbancí (jizvy, naklonění kmene a obnažený kořenový systém).

Pro dendrogeomorfologickou analýzu bylo využito celkem 48 vrtných jader z 16 disturbovaných smrků ztepilých (Picea abies). Průměrná délka chronologie je 75,2 let (směrodatná odchylka: 23,3 let), přičemž nejstarší strom byl datovaný do roku 1870 (147 let) a délka nejkratšího záznamu byla 53 let. U většiny stromů však nebylo možné identifikovat jejich stáří z důvodu pokročilého stádia rozkladu středových letokruhů ve kmenech. Celkem bylo identifikováno 49 růstových disturbancí (průměrně 3,1 disturbancí/strom), z toho 19 jizev a 30 TRD (tab. 1). Až 79,6 \% růstových disturbancí bylo možné označit jako jasné signály povodní, zatímco slabé TRD tvořily 20,4 \% všech zjištěných disturbancí.

Tab. 1. Počet a relativní zastoupení identifikovaných růstových disturbancí

\begin{tabular}{|c|c|c|c|}
\hline \multicolumn{2}{|c|}{ Typ růstové disturbance } & Počet & $\%$ \\
\hline \multicolumn{2}{|l|}{ jizvy } & 19 & 38,8 \\
\hline \multirow{3}{*}{ TRD } & silné & 8 & 16,3 \\
\hline & středně silné & 12 & 24,5 \\
\hline & slabé & 10 & 20,4 \\
\hline \multicolumn{2}{|c|}{ celkem } & 49 & 100,0 \\
\hline
\end{tabular}

Tučně jsou vyznačeny růstové distrubance, které lze považovat za jednoznačné signály hydrogeomorfologických událostí (Stoffel a Corona 2014) 
Na základě expertního přístupu bylo identifikováno celkem 11 povodňových událostí v období mezi roky 1952 - 2016 (alespoň 10 stromů tvořících chronologii), což představuje dobu opakování 5,9 let. Nejstarší datovanou událostí a zároveň událostí s největším počtem disturbovaných stromů (6 jizev a 1 TRD) je povodeň v roce 1958. Naopak nejmladším zjištěným rokem výskytu povodně je rok 2013. Pět událostí bylo identifikováno na základě třech narušených stromů (1967, 1979, 2000, 2009 a 2013). U let 1963, 1965, 1976, 2001 a 2005 byly zjištěny dvě růstové disturbance (obr. 3 ).

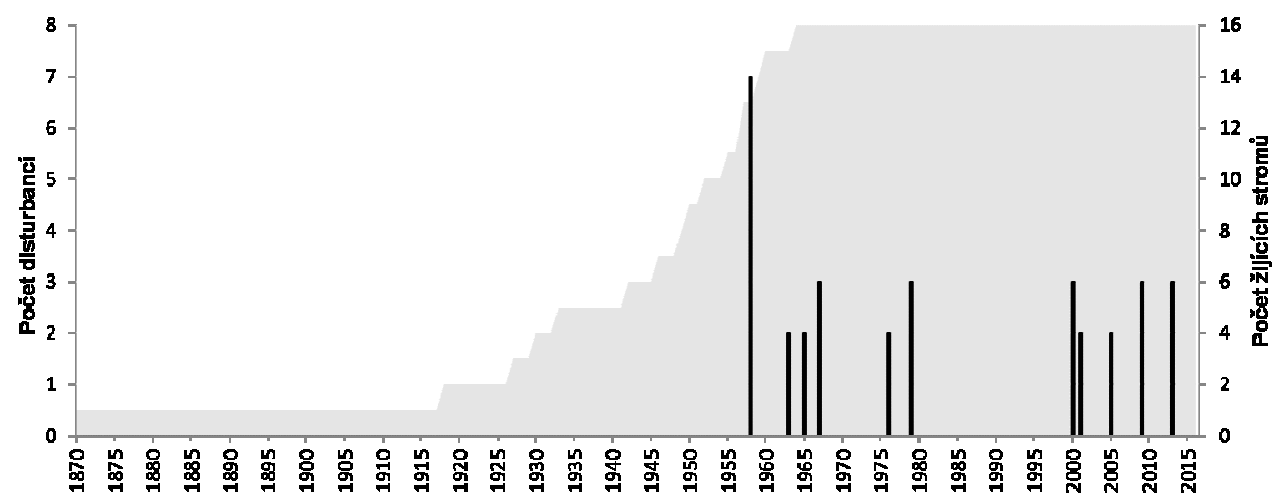

Obr. 3. Chronologie povodní na Vel'kém Studeném potoce identifikovaná pomocí dendrogeomorfologických metod (1870 - 2015)

Zjištěná chronologie událostí vykazuje dvě aktivnější období výskytu povodní, a to mezi roky 1958 - 1979 (celkem 6 událostí) a mezi roky $2000-2013$ (celkem 5 událostí). V 80. a 90. letech nebyl identifikován signifikantní dendrogeomorfologický záznam výskytu povodní.

Povodňová událost $\mathrm{z}$ roku 1958 byla jako jediná potvrzena $\mathrm{v}$ rámci celé délky studovaného úseku (viz prostorové rozmístění disturbovaných stromů na obr. 4). Ostatní události vzhledem $\mathrm{k}$ omezenému množství identifikovaných růstových disturbancí jsou zaznamenány pouze v dílčích úsecích. Odlišná prostorová distribuce je tak patrná např. v letech 1979 (dendrogeomorfologický záznam vykazuje pouze horní část úseku) a 2009 (záznam vykazuje pouze dolní část úseku).

\section{DISKUZE}

Výsledky dendrogeomorfologického výzkumu přispěly $\mathrm{k}$ vytvoření minimální chronologie povodňových událostí ve Vel'ké Studené dolině na jižních svazích Vysokých Tater. Tato část je $\mathrm{z}$ hlediska frekvence a prostorového výskytu povodní zatím spíše neprobádanou oblastí, a proto jsou získaná data o to cennější. Zároveň je ale potřeba dodat, že dendrogeomorfologický výzkum je zde omezen prostorově pouze na lokality s lesním porostem, který nebyl poškozen větrnými kalamitami $\mathrm{z}$ let 2004 a 2014.

Výsledná chronologie událostí je kombinací historicky doložených povodňových událostí z hor nebo z předpolí (např. z let 1958 a 2001; Pacl 1959, St'astný a Majerčáková 2003, Kidová et al. 2016) a doposud neznámých povodní (např̀. z let 1967, 1976 nebo 1979). Kidová et al. (2016) potvrzují klesající trend frekvence 
povodní s velkým magnitudem v předpolí Tater na řece Belá v období 1929 2008, zatímco u slabších povodní se potvrdil opačný trend. Ukazuje se, že povodeň z roku 1958 byla mimořádnou událostí a zanechala tak na stromech největší odezvu, zatímco mladší (a pravděpodobně i slabší) události jsou zaznamenané spíše sporadicky. Není však vyloučeno, že při povodni v roce 1958 mohlo dojít v některých úsecích $\mathrm{k}$ zahloubení toku a stromy rostoucí na okolních terasách už při současných zvýšených průtocích nemusí být v dosahu povodňové vlny. Menší počet růstových disturbancí u současných událostí může být rovněž vysvětlen sníženou schopností smrku ztepilého zaznamenat růstovou odezvu s rostoucím stárím stromu. Tlustší kůra může eliminovat nárazy klastů a lépe tak chránit strom než před téměř 70 lety, kdy průměrný věk námi vzorkovaných stromů mohl kolísat mezi 40 - 60 roky a jejich citlivost tak byla vyšší (Tichavský a Šilhán 2016).
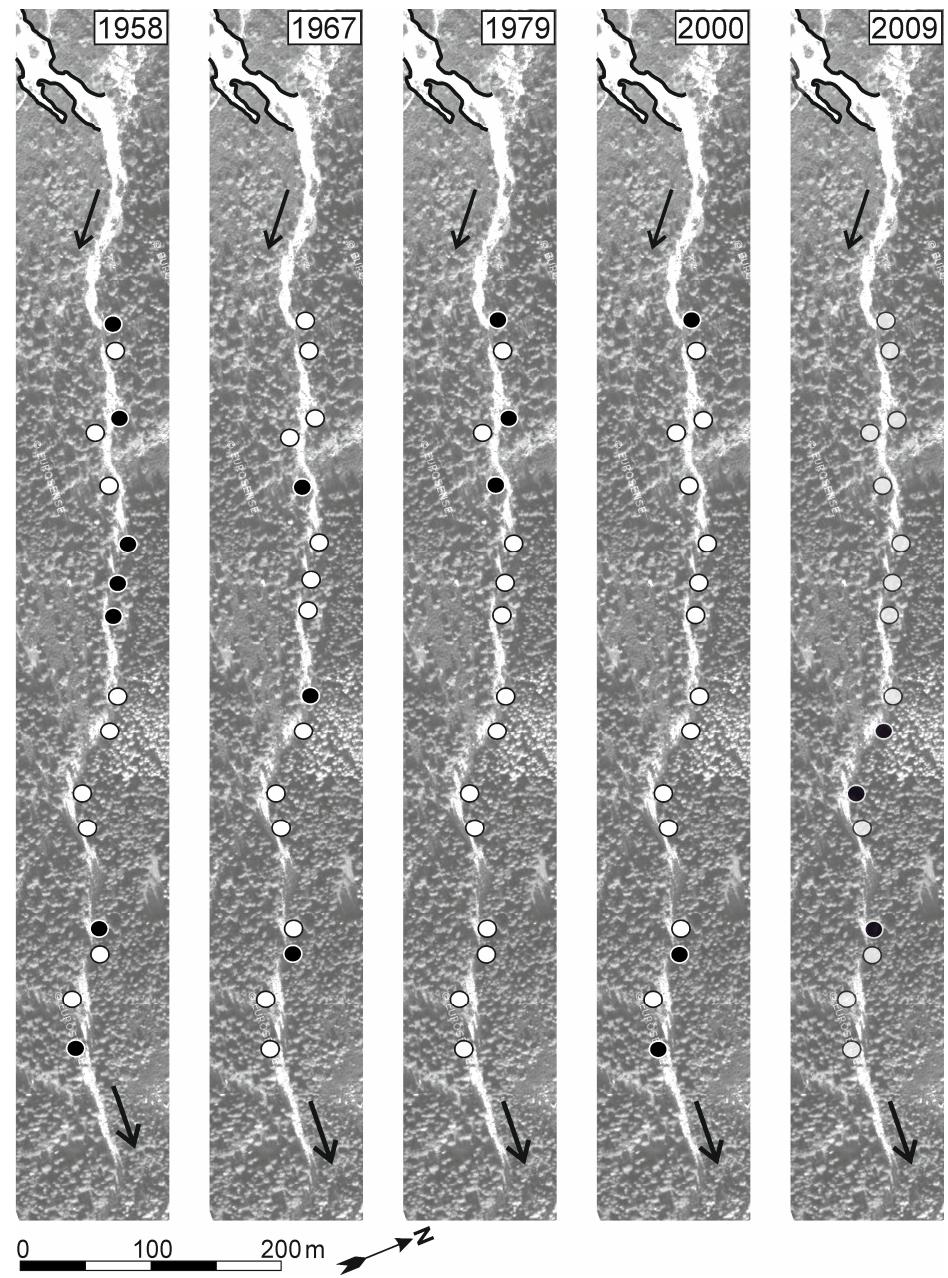

Obr. 4. Prostorová rekonstrukce vybraných povodňových událostí

Černě jsou vyznačeny stromy disturbované v daném roce, bíle ostatní vzorkované stromy. Šipky znázorňují směr proudění. V horní části je zvýrazněna dráha blokovobahenního proudu ústící do Vel'kého Studeného potoka. Podkladová data: EUROSENSE (2015). 
Některé roky výskytu současných povodní (2000, 2009 a 2013) korelují s výskytem blokovobahenních proudů ve Vel'ké Studené dolině (srov. Silhán a Tichavský 2016). Zvýšená frekvence gravitačních svahových procesů v posledních letech má za následek i prodlužování transportních drah a jejich konektivitu s hlavním tokem. Je tedy více než pravděpodobné, že růstové disturbance ze zmiňovaných let jsou odezvou na hyperkoncentrovaný proud typu debris flood, jenž vznikl v důsledku transformace $\mathrm{z}$ původního blokovobahenního proudu. Při současném globálním nárůstu průměrných teplot a předpokládané degradaci permafrostu $\mathrm{v}$ nejvyšších částech pohoří (Gądek and Leskiewicz 2012) lze očekávat jak zvýšenou četnost blokovobahenních proudů, tak i povodní v důsledku zmíněné konektivity svahů a vodních toků.

Dendrogeomorfologický výzkum povodní na severních svazích Vysokých Tater (Polsko) vykazuje rovněž shodné roky výskytu událostí. Na Rybim potoku pod Rysmi byl potvrzen výskyt povodní v letech 1958 a 1979, v Dolině Chocholowske $\mathrm{v}$ roce 1963 a na Strazyskim potoku v roce 1976 (Ballesteros-Cánovas et al. 2015a). Zielonka et al. (2008) na Waksmundzkim potoku také identifikoval povodeň z roku 1958. Dendrogeomorfologický výzkum ve Vel'ké Studené dolině naopak neodhalil událost z roku 1973, která výrazně zasáhla především návětrnou (severní) stranu Tater (Niedzwiedz et al. 2015). Ukazuje se tak, že role orografického zesílení srážek na návětrné straně hor hraje důležitou roli z hlediska výskytu povodňových událostí.

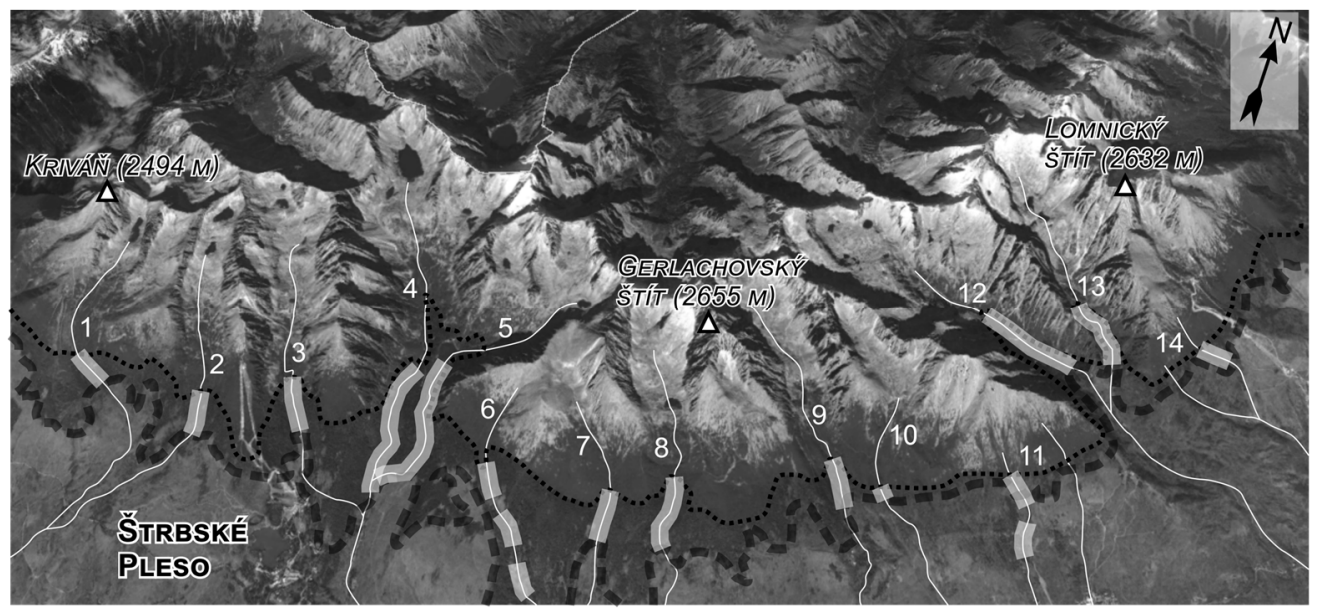

Obr. 5. Úseky vodních toků na jižních svazích Vysokých Tater potenciálně vhodné $\mathrm{k}$ dendrogeomorfologické rekonstrukci povodní (v mapě zvýrazněny)

Délka vhodných úseků je ovlivněna dolní hranicí, kde již zasahuje polom po větrných kalamitách (čárkovaná čára) a horní hranicí lesa, kde smrkový les přechází v klečový vegetační stupeň (tečkovaná čára). 1 - Biely Váh, 2 - Furkotský potok, 3 - Mlynica, 4 - Hincov potok, 5 - Krupá, 6 - Vel'ký Šum, 7 - Malý Šum, 8 - Batizovský potok, 9 - Velický potok, 10 - Slavkovský potok, 11 - Stiavnik, 12 - Vel'ký Studený potok, 13 - Malý Studený potok, 14 - Chotárny potok. Podkladový snímek: Google Earth C2017.

Vzorkování malého počtu stromů v rámci dendrogeomorfologických výzkumů není ničím neobvyklým. Stoffel a Bollschweiler (2009) popisují možnosti a limity identifikace událostí blokovobahenních proudů na základě analýzy 35 stromů. Ball- 
esteros-Cánovas et al. (2015a) identifikovali povodňové události v polských Tatrách z 21 stromů v Dolině Raztoka, respektive z 22 stromů na Strazyskim potoku. Vaidean et al. (2015) vzorkovali 20 stromů pro analýzu procesů typu debris flood v rumunských Karpatech. S klesajícím počtem vzorkovaných stromů roste pravděpodobnost nekompletní chronologie. Dendrogeomorfologické rekonstrukce velmi často reprezentují minimální frekvence událostí, protože některé události mohou být $\mathrm{v}$ letokruhových sériích setřeny (Bollschweiler et al. 2011). Nízký počet stromů vykazujících jizvy lze rovněž vysvětlit slabším geomorfologickým impaktem povodňových událostí v dané oblasti (Raczkowska 2006). Nicméně pokud jsou toky dotované o sedimenty z bočních drah blokovobahenních proudů, je pravděpodobné, že materiál bude dále přeplavován v podobě procesů typu debris flood, který může poškodit břehovou vegetaci.

Tab. 2.Přehled vybraných toků jižních svahů Vysokých Tater a délka úseků procházející lesním porostem. Tučně jsou vyznačeny toky potenciálně vhodné k dendrogeomorfologické rekonstrukci povodní.

\begin{tabular}{|c|c|c|}
\hline Kód & Název vodního toku & $\begin{array}{l}\text { Délka toku procházející } \\
\text { živým smrkovým porostem }\end{array}$ \\
\hline$\overline{1}$ & Biely Váh & $500 \mathrm{~m}$ \\
\hline 2 & Furkotský potok & $900 \mathrm{~m}$ \\
\hline 3 & Mlynica & $700 \mathrm{~m}$ \\
\hline 4 & Hincov potok & $1800 \mathrm{~m}$ \\
\hline 5 & Krupá & $2000 \mathrm{~m}$ \\
\hline 6 & Vel'ký Šum & $500 \mathrm{~m}(2100 \mathrm{~m})^{* 1}$ \\
\hline 7 & Malý Šum & $700 \mathrm{~m}$ \\
\hline 8 & Batizovský potok & $800 \mathrm{~m}$ \\
\hline 9 & Velický potok & $900 \mathrm{~m}$ \\
\hline 10 & Slavkovský potok & $300 \mathrm{~m}$ \\
\hline 11 & Štiavnik & $200 \mathrm{~m}(1200 \mathrm{~m})^{*_{1}}$ \\
\hline 12 & Vel'ký Studený potok & $1000 \mathrm{~m}$ \\
\hline 13 & Malý Studený potok & $500 \mathrm{~m}$ \\
\hline 14 & Chotárny potok & $600 \mathrm{~m}^{* 2}$ \\
\hline
\end{tabular}

*1 úsek s otevřeným lesním porostem

*2 úsek ovlivněný lavinovými drahami

^ dendrogeomorfologický výzkum proveden

I přes jistá omezení se dá tvrdit, že analýza malého počtu vzorků je cennou a především časově nenáročnou metodou identifikace povodňových událostí v horských zalesněných tocích bez hydrologických záznamů. Dendrogeomorfologický výzkum povodní na jižních svazích Vysokých Tater tak může být rozšířen o další neprozkoumaná povodí. Obr. 5 nastiňuje potenciál k dendrogeomorfologickému výzkumu s ohledem na současný stav lesního porostu v oblastech po rozsáhlých větrných kalamitách v letech 2004 a 2014. V př́ipadě dostatečné délky pásu lesního porostu podél vodního toku (tak jako ve Vel'kém Studeném potoce) se zdá být dendrogeomorfologický výzkum uplatnitelný. Z tohoto pohledu se jeví jako vhodné potenciální oblasti Furkotský potok, Hincov potok, Krupá nebo Velický potok (tab. 2). Naopak centrální část jižních svahů (např. Slavkovský potok či Stiavnik) lze prakticky vyloučit. Z hlediska dynamiky toku přichází v úvahu výzkum na Malém 
Studeném potoce, ale otázkou zůstává, zda se v 500 m dlouhém úseku najde dostatečný počet disturbovaných stromů. Další variantou je zahrnout do dendrogeomorfologického výzkumu i úseky porostlé borovicí klečí a pokusit se identifikovat a datovat povodňové jizvy, stejně jako tomu bylo při výzkumu blokovobahenních proudů a lavin (Šilhán a Tichavský 2016 a 2017). Pro zpřesnění chronologie recentních událostí pak navrhujeme zahrnout i analýzu a datování obnažených (popř. zajizvených) kořenů stromů (Stoffel et al. 2012). Tuto metodu lze použít za předpokladu, že tok svou erozní činností způsobil obnažení kořenového systému ve studovaných lokalitách.

\section{ZÁVĚR}

Aplikací dendrogeomorfologických metod se podařilo zrekonstruovat výskyt povodňových událostí na Vel'kém Studeném potoce ve Vysokých Tatrách za posledních cca sedmdesát let. I přes limitující podmínky způsobené větrnými kalamitami, a tudíž nemožností vzorkovat stromy v úseku pod $1350 \mathrm{~m} \mathrm{n}$. m., lze tvrdit, že i z nízkého počtu vzorkovaných stromů (16) bylo možné sestavit alespoň minimální chronologii událostí. Tato data jsou o to cennější, že ve studovaném území nejsou systematicky měřeny průtoky a není zde prováděn ani jakýkoliv monitoring. Recentní zvýšení frekvence gravitačních svahových procesů v horských údolích Tater může mít odezvu i v nižších partiích bystřinných toků, a proto je potřeba řešit danou problematiku systematicky (existuje-li vazba mezi svahovými a fluviálními procesy a dochází-li ke konektivitě aktivních drah blokovobahenních proudů s vodními toky).

Pro detailnější informace o srážko-odtokové odezvě z jižních svahů Tater je však potřeba rekonstruovat události z většího množství dílčích povodí. Dendrogeomorfologický výzkum se ukazuje jako použitelný pouze ve vybraných povodích $\mathrm{z}$ důvodu silných disturbancí na lesním porostu způsobených větrnými kalamitami během posledních 10 - 15 let. Pokud se podaří získat dendrogeomorfologická data alespoň z dalších tří až pěti dílčích povodí, je možné porovnávat získané chronologie událostí, identifikovat místa s největší frekvencí výskytu povodní a zároveň poukázat na nejkritičtější zóny z hlediska potenciálního hazardu v podhorských oblastech. I proto jsou dendrogeomorofologické rekonstrukce povodňových událostí základním kamenem pro komplexní výzkum daného fenoménu a jeho predikci do budoucna i s ohledem na měnící se klimatické podmínky.

Př́spěvek vznikl za finanční podpory studentské grantové soutěže specifického vysokoškolského výzkumu SGS05/Přf/2017-2018 „Poznání vývoje a současného stavu krajiny Západnich Karpat a východosudetských pohoři s ohledem na činnost člověka a současných př́rodních hazardü“. Autoři zároveň děkují dvou anonymním recenzentuim za př́nosné komentáře a rady, které vedly $k$ vylepšení kvality článku.

\section{LITERATURA}

ALESTALO, J. (1971). Dendrochronological interpretation of geomorphic processes. Fennia, 105, 1-140.

APEL, H., THIEKEN A. H., MERZ, B., BLÖSCHL, G. (2004). Flood risk assessment and associated uncertainty. Natural Hazards and Earth System Science, 4, 295-308.

BALLESTEROS-CÁNOVAS, J. A., EGUIBAR, M., BODOQUE, J. M., DÍEZHERRERO, A., STOFFEL, M., GUTIÉRREZ-PÉREZ, I. (2011). Estimating flash flood 
discharge in an ungauged mountain catchment with 2D hydraulic models and dendrogeomorphic palaeostage indicators. Hydrological Processes, 25, 970-979.

BALLESTEROS-CÁNOVAS, J. A., CZAJKA, B., JANECKA, K., LEMPA, M., KACZKA, R. J., STOFFEL, M. (2015a). Flash floods in Tatra Mountain streams: frequency and triggers. Science of the Total Environment, 511, 639-648.

BALLESTEROS-CÁNOVAS， J. A., RODRIGUEZ-MORATA， C., GARÓFANOGÓMEZ, V., RUBIALES, J. M., SẢNCHEZSALGUERO, R., STOFFEL, M. (2015b). Unravelling past flash flood activity in a forested mountain catchment of the Spanish central system. Journal of Hydrology, 529, 468-479.

BARNETT, T., ADAM, J., LETTENMAIER, D. (2005). Potential impacts of a warming climate on water availability in snow-dominated regions. Nature, 438, 303-309.

BOLLSCHWEILER, M., STOFFEL, M., EHMISCH, M., MONBARON, M. (2007). Reconstructing spatio-temporal patterns of debris-flow activity using dendrogeomorphological methods. Geomorphology, 87, 337-351.

BOLLSCHWEILER, M., STOFFEL, M. (2009). What tree rings can tell about Earthsurface processes: teaching the principles of dendrogeomorphology. Geography Compass, 3, 1013-1037.

BOLLSCHWEILER, M., STOFFEL, M., SCHLÄPPY, R. (2011). Debris-flood reconstruction in a pre-alpine catchment in switzerland based on tree-ring records of coniferous and broadleaved trees. Geografiska Annaler: Series A, Physical Geography, 93, 1-15.

BORGA, M., STOFFEL, M., MARCHI, L., MARRA, F., JAKOB, M. (2014). Hydrogeomorphic response to extreme rainfall in headwater systems: flash floods and debris flows. Journal of Hydrology, 518, 194-205.

The CGIAR Consortium for Spatial Information (2017). SRTM 90m Digital Elevation Database v4.1, [Online]. Available: http://www.cgiar-csi.org/data/srtm-90m-digitalelevation-database-v4-1 [accessed 1 June 2017].

COOK, E. R. (1985). A time series analysis approach to tree-ring standardization. $\mathrm{PhD}$ thesis. University of Arizona, Tucson.

DANIHLÍK, R., TRIZNA, M. (2005). Vplyv klimatickej zmeny na režim odtoku vo vybraných povodiach Slovenska. Geografický časopis, 57, 57-70.

ENGEL, Z., MENTLÍK, P., BRAUCHER, R., MINÁR, J., LÉANNI, L., TEAM, A. (2015). Geomorphological evidence and ${ }^{10} \mathrm{Be}$ exposure ages for the Last Glacial Maximum and deglaciation of the Velká and Malá Studená dolina valleys in the High Tatra Mountains, Central Europe. Quaternary Science Reviews, 124, 106-123.

EUROSENSE (2015). Letecké snimky, [Online]. Available: http://www.mapy.cz [accessed 1 June 2017].

GĄDEK, B., LESKIEWICZ, J. (2012). Impact of climate warming on the ground surface temperature in the sporadic permafrost zone of the Tatra Mountains, Poland and Slovakia. Cold Regions Science and Technology, 79-80, 75-83.

GAUME, E., BAIN, V., BERNARDARA, P., NEWINGER, O., BARBUC, M., BATEMAN, A., BLAŠKOVIČOVÁ, L., BLÖSCHL, G., BORGA, M., DUMITRESCU, A., DALIAKOPOULOS, I., GARCIA, J., IRIMESCU, A., KOHNOVA, S., KOUTROULIS, A., MARCHI, L., MATREATA, S., MEDINA, V., PRECISO, E., SEMPERETORRES, D., STANCALIE, G., SZOLGAY, J., TSANIS, I., VELASCO, D., VIGLIONE, A. (2009). A compilation of data on European flash floods. Journal of Hydrology, $367,70-78$.

GOMI, T., SIDLE, R. C., SWANSTON, D. N. (2004). Hydrogeomorphic linkages of sediment transport in headwater streams, Maybeso Experimental Forest, southeast Alaska. Hydrological Processes, 18, 667-683.

GREŠKOVA, A. (2001). Identifikácia rizikových oblastí a rizikových faktorov vzniku povodní v malých povodiach. Geografický časopis, 53, 247-268.

HLAVATÁ, H., HOLKO, L., KOSTKA, Z., NOVÁ, J. (2008). Analýza zrážkovo - odtokových vzt’ahov v malých povodiach Vysokých Tatier. In Sír, M. Tesař, M., Lichner, L., eds. Proceedings of International Conference Hydrologie malého povodí 2008. Praha (Ústav pro hydrodynamiku AV ČR v.v.i.), pp. 99-106. 
HLOSKA, L., CHOVANCOVÁ, B., CHOVANCOVÁ, G., FLEISCHER, P. (2016). Influence of climatic factors on the population dynamics of small mammals (Rodentia, Soricomorpha) on the sites affected by windthrow in the High Tatra Mts. Folia Oecologica, $43,12-20$.

HOLKO, L., KOSTKA, Z., DANKO, M., LIOVÁ, S. (2011). Hydrologický cyklus v horskom prostredí. Životné prostredie, 45, 59-63.

JAKOB, M., HUNGR, O. (2005). Debris-flow hazards and related phenomena. Chichester (Springer-Praxis).

KACZKA, R., LEMPA, M., CZAJKA, B., JANECKA, K., RACZKOWSKA, Z., HREŠKO, J., BUGAR, G. (2015). The recent timberline changes in the Tatra Mountains: a case study of the Mengusovská valley (Slovakia) and the Rybi potok valley (Poland). Geographia Polonica, 88, 71-83.

KIDOVÁ, A., LEHOTSKÝ, M., RUSNÁK, M. (2016). Geomorphic diversity in the braided-wandering Belá River, Slovak Carpathians, as a response to flood variability and environmental changes. Geomorphology, 272, 137-149.

KONČEK, M., ed. (1974). Klíma Tatier. Bratislava (Veda).

KOREŇ, M. (2005). Vetrová kalamita 19. novembra 2004: nové pohlady a konsekvencie. Tatry, 44, 6-28.

KOTARBA, A. (1992). High-energy geomorphic events in the Polish Tatra Mountains. Geografiska Annaler: Series A, 74, 123-131.

LEHOTSKÝ, M., LACIKA, J. (2007). Typy segmentov dolinovo-riečnych systémov S velvysočinovou zdrojovou zónou: príklad Tatier. Geomorphologica Slovaca et Bohemica, 1, 27-35.

MARCHI, L., BORGA, M., PRECISO, E., GAUME, E. (2010). Characterisation of selected extreme flash floods in Europe and implications for flood risk management. Journal of Hydrology, 394, 118-133.

NIEDZWIEDZ, T. (1992). Climate of the Tatra Mountains. Mountain Research and Development, 12, 131-146.

NIEDZWIEDZ, T., ŁUPIKAZSA, E., PINSKWAR, I., KUNDZEWICZ, Z. W., STOFFEL, M., MALARZEWSKI, Ł. (2015). Variability of high rainfalls and related synoptic situations causing heavy floods at the northern foothills of the Tatra Mountains. Theoretical and Applied Climatology, 119, 273-284.

PACL, J. (1959). Katastrofálna povoden̆ v oblasti Tatier v júni 1958. Zborník prác o Tatranskom národnom parku, 3, 17-56.

PEKÁROVÁ, P., SVOBODA, A., MIKLÁNEK, P., ŠKODA, P., HALMOVÁ, D., PEKÁR, J. (2012). Estimating flash flood peak discharge in Gidra and Parná basin: case study for the 7-8 June 2011 flood. Journal of Hydrology and Hydromenchanics, 60, 206-216.

PLESNÍK, P. (1971). Horná hranica lesa vo Vysokých a Belanských Tatrách. Bratislava (SAV).

RĄCZKOWSKA, Z. (2006). Recent geomorphic hazards in the Tatra Mountains. Studia Geomorphologica Carpatho-Balcanica, 40, 45-60.

RUIZ-VILLANUEVA, V., STOFFEL, M., WYZGA, B., KUNDZEWICZ, Z. W., CZAJKA, B., NIEDZWIEDZ, T. (2016). Decadal variability of floods in the northern foreland of the Tatra Mountains. Regional Environmental Change, 16, 603-615.

SCHNEUWLY-BOLLSCHWEILER, M., CORONA, C., STOFFEL, M. (2013). How to improve dating quality and reduce noise in tree-ring based debris-flow reconstructions. Quaternary Geochronology, 18, 110-118.

SCHWEINGRUBER, F. H. (1996). Tree rings and environment. Dendroecology. Birmensdorf (WSL, Haupt).

SHRODER, J. F. (1978). Dendrogeomorphological analysis of mass movement on Table Cliffs Plateau, Utah. Quarternary Research, 9, 168-185.

SOLÍN, L. (2008) Analýza výskytu povodňových situácií na Slovensku v období rokov 1996-2006. Journal of Hydrology and Hydromechanics, 56, 95-115. 
STANKOVIANSKY, M., MIDRIAK, R. (1998). The recent and present-day geomorphic processes in Slovak Carpathians. State of arts review. Studia Geomorphologica Carpatho-Balcanica, 22, 69-87.

STRAHLER, A. N. (1957). Quantitative analysis of watershed geomorphology. Transactions of the American Geophysical Union, 38, 913-920.

STOFFEL, M. (2008). Dating past geomorphic processes with tangential rows of traumatic resin ducts. Dendrochronologia, 26, 53-60.

STOFFEL, M., BOLLSCHWEILER, M. (2008). Tree-ring analysis in natural hazards research-an overview. Natural Hazards and Earth System Science, 8, 187-202.

STOFFEL, M., BOLLSCHWEILER, M. (2009). Tree-ring reconstruction of past debris flows based on a small number of samples - possibilities and limitations. Landslides, 6 , 225-230.

STOFFEL, M., CASTELlER, A., LUCKMAN, B. H., VILLALBA, R. (2012). Spatiotemporal analysis of channel wall erosion in ephemeral torrents using tree roots - an example from the Patagonian Andes. Geology, 40, 247-250.

STOFFEL, M., CORONA, C. (2014). Dendroecological dating of geomorphic disturbance in trees. Tree-Ring Research, 70, 3-20.

STOFFEL, M., WILFORD, D. J. (2012). Hydrogeomorphic processes and vegetation: disturbance, process histories, dependencies and interactions. Earth Surface Processes and Landforms, 37, 9-22.

ŠILHÁN, K., TICHAVSKÝ, R. (2016). Recent increase in debris flow activity in the Tatra Mountains: results of a regional dendrogeomorphic reconstruction. Catena, 143, 221231.

ŠILHÁN, K., TICHAVSKÝ, R. (2017). Snow avalanche and debris flow activity in the High Tatras Mountains: new data from using dendrogeomorphic survey. Cold Regions Science and Technology, 134, 45-53.

ŠŤASTNÝ, P., MAJERCÁKOVÁ, O. (2003). Rekonštrukcia štrbskej povodne v júli 2001. In Hydrológia na prahu 21. storocia - Vizie a realita. Sborník z konference, Smolenice, 5. - 7. 5. 2003,CD-ROM.

TICHAVSKÝ, R., ŚILHÁN, K. (2015). Rekonstrukce murové dráhy v povodí Keprnického potoka (Hrubý Jeseník) na základě dendrogeomorfologických metod. Zprávy o geologických výzkumech, 48, 65-70.

TICHAVSKYY, R., SILHÁN, K. (2016). The changing ability of Norway spruce to record hydro-geomorphic processes based on the age and diameter of the tree stem - a dendrogeomorphic approach. Catena, 147, 469-480.

TICHAVSKÝ, R., ŠILHÁN, K., TOLASZ, R. (2017). Tree-ring based chronology of hydro -geomorphic processes as a fundament for identification of hydro-meteorological triggers in the Hrubý Jeseník Mountains (Central Europe). Science of the Total Environment, 579, 1904-1917.

TSAKIRIS, G. (2014). Flood risk assessment: concepts, modelling, applications. Natural Hazards and Earth System Science, 14, 1361-1369.

VAIDEAN, R., ARGHIUS, V., POP, O. (2015). Dendrogeomorphic reconstruction of past debris-flood activity along a torrential channel: an example from Negoiul basin (Apuseni Mountains, Romanian Carpathians). Zeitschrift für Geomorphologie, 59, 319335.

VIAS - VIENNA INSTITUTE OF ARCHAEOLOGICAL SCIENCE (2005). Time table. Installation and instruction manual. Ver. 2.1, Vienna.

VOJTEK, M. (2004). Štatistické spracovanie historických lavinových záznamov od r. 1850 $z$ hladiska meteorologických podmienok vo Vysokých Tatrách. Př́íspěvek prezentovaný na Bioklimatologických Pracovných Dňoch 2004, Viničky 23.-26.8.2004.

WILFORD, D. J., SAKALS, M. E., INNES, J. L., SIDLE, R. C., BERGERUD, W. A. (2004). Recognition of debris flow, debris flood and flood hazard through watershed morphometrics. Landslides, 1, 61-66.

ZIELONKA, T., HOLEKSA, J., CIAPAŁA, S. (2008). A reconstruction of flood events using scarred trees in the Tatra Mountains, Poland. Dendrochronologia, 26, 173-183. 


\section{Radek Tichavský, Hana Př ecechtělová \\ DENDROGEOMORPHIC RESEARCH OF FLOODS \\ IN THE VELKÝ STUDENÝ POTOK CREEK (THE HIGH TATRA MTS.)}

Flash floods are one of the most common hydrogeomorphic phenomena that occur on the southern slopes of the High Tatra Mts. (northern Slovakia). However, this part has not been investigated before concerning the frequency of flood events due to a lack of historical records. The applicability of dendrogeomorphic methods for the reconstruction of the frequency of flood events was tested in the Vel'ká Studená dolina Valley. Unfortunately, the whole region was affected by severe wind calamities in 2004 and 2014 that destroyed many trees growing on slopes and nearby the streams. That is why there were limited options for tree sampling. Therefore, the aim was to find out if such research based on a limited amount of sampled trees is sufficient to create the chronology of flood events in this region.

We sampled all trees growing along the stream (at an altitude of between $1350-1450$ $\mathrm{m}$ a. s. 1.) which provided clear evidence of past hydrogeomorphic activity (i.e. the presence of flood scars). In total, 16 individuals of Picea abies (L.) Karst were sampled to obtain 48 increment cores used for the analysis of tree-ring series. The methodology followed the semi-quantitative approach of dendrogeomorphic methods. Only the presence of scars and/ or tangential rows of traumatic resin ducts (TRD) was considered as an unequivocal signal of floods. To determine the event, we had to set a threshold of two growth disturbances occurring during the same year.

Based on this approach we identified 11 flood events during the period $1952-2016$. The oldest event year 1958 showed the highest number of growth disturbances (six scars and one TRD). In addition, our data revealed two periods with a higher frequency of flood events (i.e. the period 1958 - 1979 with six events and the period $2000-2013$ with five events). Two identified events (2009 and 2013) coincided with the occurrence of debris flows in the Vel'ká Studená dolina Valley while some other events (e.g. in 1963 and 1976) occurred simultaneously on the northern slopes of the High Tatra Mts.

We were able to set the minimum chronology of flood events based on 16 disturbed trees. Even though the tree-ring reconstruction may be incomplete due to the lower number of sampled trees, it seems to be a reliable approach if other research options are not possible. Therefore, we call for the completion of records from the other streams on southern slopes with sufficiently long forested reaches (such as the Furkotský potok creek or the Hincov potok creek). 
- 